\title{
PENENTUAN KAWASAN PERTAMBANGAN BERBASIS SEKTOR KOMODITAS UNGGULAN SUMBERDAYA NIKEL KABUPATEN KONAWE DAN KONAWE UTARA PROVINSI SULAWESI TENGGARA
}

\author{
Oleh: \\ *Iwan Nursahan, **Vijaya Isnaniawardhani dan **Nana Sulaksana \\ *Pusat Sumber Daya Geologi \\ Jalan Soekarno-Hatta No.444, Bandung \\ **Fakultas Teknik Geologi, Universitas Padjadjaran \\ Jalan Raya Bandung-Sumedang Km.21, Jatinangor
}

\section{SARI}

Kabupaten Konawe dan Kabupaten Konawe Utara merupakan bagian dari Kawasan Strategis Nasional (KSN) Soroako dan sekitarnya, yang dicanangkan sebagai wilayah dengan komoditi unggulan pertambangan nikel. Penentuan kawasan pertambangan berbasis komoditi unggulan sumberdaya nikel ini menggunakan pendekatan Satuan Genetika Wilayah (SGW) dan memanfaatkan Teknologi Sistem Informasi Geografis (SIG).

Valuasi matrik holistik SGW menghasilkan 204 nilai SGW di Kabupaten Konawe dan 248 nilai SGW di Kabupaten Konawe Utara. Valuasi matrik holistik tersebut, menunjukkan adanya keterkaitan aspek potensi dan kendala wilayah terhadap total nilai valuasi SGW.

Berdasarkan valuasi SGW dan analisis SWOT kawasan pertambangan prioritas I, maka dapat direkomendasikan bahwa SGW Pedataran Patahan Batuan Ultramafik daerah Langikima dan Wiwirano serta SGW Pedataran Batuan Ultramafik daerah Asera, Andowia, Wiwirano dan Molawe sebagai Kawasan Andalan Pertambangan Nikel, dengan total sumberdaya sekitar 1,14 Milyar Ton, dan nilai valuasi skenario dikembangkan/ditambang berkisar 248 hingga 298.

Kata kunci: kawasan pertambangan, nikel, valuasi.

\section{ABSTRACT}

Konawe and Konawe Utara Regenciesare part of the Sorowako National Strategic Area and surroundings, which was declared as the nickel mining commodity area. This study aims to determine the terrain development priority based of nickel resources approaches by the Terrain Genetic Unit (TGU) using Geographic Information Systems (GIS) technology.

The valuation of holistic matrix TGU, obtained 204 values in Konawe Regency and 248 values of TGU at Konawe Utara Regency. The holistic matrix valuation shows the relationship between the potential and constrains value of Terrain characteristic toward the total TGU values.

Based on theTGU valuation and SWOT analysis for first priority mining areas, it can be recommended that the TGU of Plain Fault ultramafic rocks around Langikima and Wiwirano areas as well as TGU of Plain ultramafic rocks around Asera,Andowia, Wiwirano and Molawe areas as the first priority zone of Nickel mining, with resource about 1.14 billion tons, and TGU value for developed/mined scenario is ranged between 248 to 298.

Keyword: mining area, nickel, valuation.

\section{PENDAHULUAN}

\section{Latar Belakang}

Dalam Masterplan Percepatan

Perluasan Pembangunan Ekonomi Indonesia (MP3El 2011 - 2025), Pulau Sulawesi diarahkan salah satunya untuk pengembangan pertambangan nikel. Berdasarkan dalam PP No. 26 tahun 2008 tentang Rencana Tata Ruang Wilayah Nasional, Kabupaten Konawe Utara dan Kabupaten Konawe ini merupakan bagian dari Kawasan Strategis Nasional (KSN) Soroako dan Kawasan Andalan Pertambangan Nikel Asesolo /Kendari, Sulawesi Tenggara.

Permasalahan utama dalam alokasi pemanfatan tataguna lahan kawasan 
pertambangan, yakni: terdapatnya tumpang tindih antara kegiatan pertambangan dengan sektor lainnya, seperti: pertanian, pemukiman dan kawasan hutan konservasi dan lindung. Salah satu alternatif untuk mencari solusi masalah tersebutadalah dengan melakukan penelitian penentuan kawasan pertambangan dengan pendekatan Konsep Satuan Genetika Wilayah (Hirnawan, 2005).

\section{Geologi Regional}

Geologi daerah penelitian didominasi oleh Satuan Batuan Ofiolit/ Ultramafik $(\mathrm{Ku})$ berumur Kapur, terdiri dari : peridotit dan hazburgit. Struktur geologi yang berkembang berupa sesar mendatar mengiri berarah baratlaut-tenggara (Sesar Lasolo). Sesar mendatar menganan Anggowala berarah baratlaut tenggara dan Sesar naik Wawo mengakibatkan beranjaknya batuan ultramafik. Lipatan ditemukan berupa lipatan tertutup, lipatan rebah, lipatan pisau dan lipatan terbalik, pada batuan Tersier, termasuk dalam Peta Geologi Lembar Lasusua-Kendari, Sulawesi, sekala 1 : 250.000, terlihat dalam gambar 1 (Rusmana, 1993). Menurut Moetamar (2007) batuan ultramafik yang terdiri dari peridotit dan hazburgit tersebut merupakan formasi pembawa logam nikel.

Potensi bijih nikel Kabupaten Konawe adalah sebesar 529,9 juta ton, dengan nilai sumber daya sebesar 460,57 juta ton, dan cadangan 69,3 juta ton, kadar $\mathrm{Ni}$ berkisar 0,6-2\%, terdapat di Kecamatan Routa, Kecamatan Puriala, Kecamatan Pondidaha. Sedangkan di Kabupaten Konawe Utara total potensi nikel adalah sebesar 501,8 juta ton, dengan nilai sumber daya sebesar 348,5 juta ton,dan cadangan 153,3 juta ton, kadar Ni dari 0,98-2,95\%, tersebar di Kecamatan Lasolo, Kecamatan Langikima, Kecamatan Molawe dan Kecamatan Wiwirano (Anonim, 2011b).

\section{Genesa Endapan Nikel}

Endapan nikel laterit dapat dibagi menjadi dua jenis: nickel ferrous ferugineous dan nickel silicate (nikel laterit silika). Nikel laterit pertama memiliki kandungan besi $40 \%$ $\mathrm{Fe}$ dan $\mathrm{Ni} \pm 1 \%$. Dan nikel laterit silika mempunyai kandungan besi $<35 \% \mathrm{Fe}$, dan $\mathrm{Ni}$ mencapai $15 \%$, terdapat pada nickel garnierite, terbentuk di bagian zona saprolit
(Chetetat,1947, dalam Sutisna, 2006). Endapan nikel laterit silika merupakan endapan yang terbentuk oleh proses residual silika bijih nikel yang berasosiasi dengan batuan ultramafik dunit, peridotit, serpentinit-harzburgit pada lingkungan tropis-subtropis berumur MesozoikumKuarter. Keterdapatan nikel di Indonesia umumnya sebagai endapan nikel laterit silika hasil pelapukan residual batuan dasar Komplek Ofiolit/Ultramafik, yang terakumulasi pada batuan peridotit serpentinit dan hazburgit (Smirnov, 1976).

Selain itu, endapan nikel juga terkonsentrasi pada morfologi dengan karakteristik ideal. Morfologi ideal ini berpengaruh terhadap efektifitas proses pelapukan, dan tingkat erosi yang diakibatkan oleh dinamika iklim tropis. Morfologi ini umumnya berbentuk dataran (plato) dengan kemiringan lereng rendah atau daerah bergelombang dengan kemiringan lereng dibawah $30^{\circ} \mathrm{C}$ (Swamidharma, 2011). Pembagian pengayaan nikel laterit berdasarkan kemiringan lereng dapat dijelaskan pada gambar 2 (Chetetat, 1947; Blanchard, 1944 dalam Gilbert dan Park, 1986).

Tipe endapan nikel laterit di Sulawesi, ditemukan terakumulasi pada lapisan saprolit dan limonit. Endapan nikel akan terakumulasi di bagian bawah saprolit dan kadarnya akan meningkat $\pm 30 \%$, dengan kisaran kadar $\mathrm{Ni} 1,5-3 \%$ (Swamidharma, 2011).

\section{Potensi Nikel}

Potensi sumber daya dan cadangan bijih nikel laterit Indonesia sekitar 4,2 milyar ton (2011), atau sepertiga dari sumber daya nikel laterit dunia yang mencapai 12,5 milyar ton. Secara nasional tahun 2010 produksi bijih nikel mencapai 5,6 juta ton, nikel matte 79 ribu ton dan ferronickel 18 ribu ton. Pada tahun 2011 produksi bijih nikel meningkat hingga 7,5 juta ton. Pada tahun 2012 diperkirakan produksi bijih nikel nasional mencapai 34 juta ton. Sedangkan produksi nikel matte diperkirakan mencapai 70 ribu ton dan ferronickel mencapai 19 ribu ton. Masih tingginya nilai ekspor bahan mentah menjadi salah satu penyebab tidak terserapnya produksi bijih nikel nasional oleh industri dalam negeri (Ignasius $L$ dan Nurseffi, D.W., 2012). 


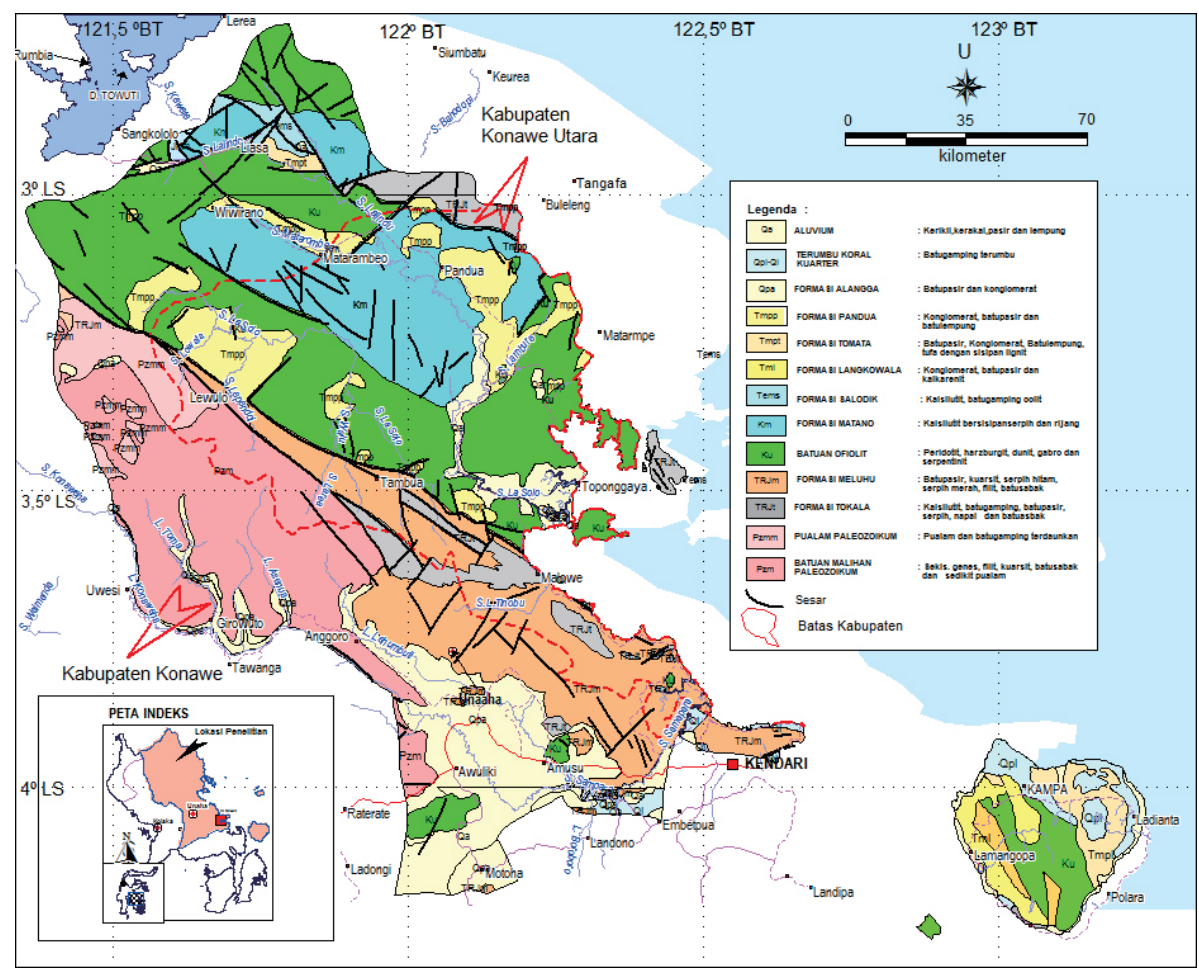

Gambar 1. Peta Geologi Kabupaten Konawe dan Kabupaten Konawe Utara (Moetamar,2007 modifikasi dari Rusmana, 1993)

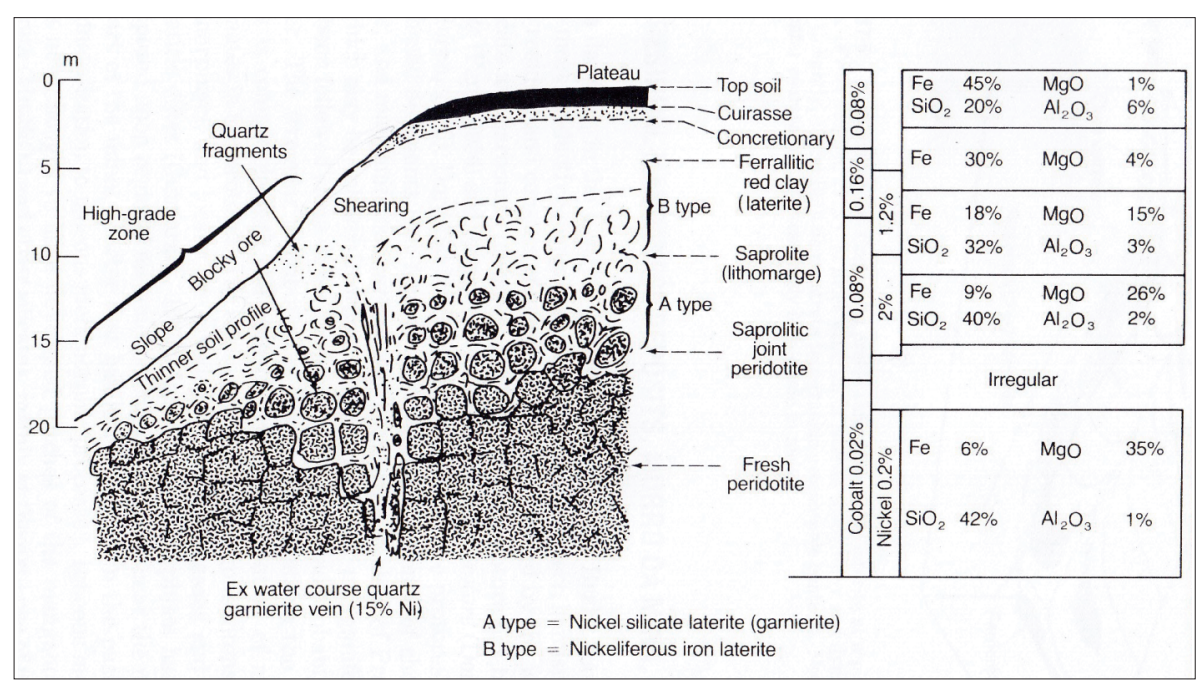

Gambar 2. Penampang tegak pengayaan cebakan nikel lateritik (Chetetat, 1947dalam Gilbert dan Park, 1986)

Pulau Sulawesi merupakan daerah penghasil nikel paling tinggi di Indonesia, yang menyumbangkan sekitar 7\% PDRB Sulawesi. Saat ini, hanya terdapat dua produsen utama dan pusat pengolahan nikel di Sulawesi Bagian Tenggara, yakni PT Aneka Tambang (Tbk) di Pomalaa Provinsi Sulawesi Tenggara sebagai Pusat Pengolahan ferronickel dengan produksi 30.000 ton, dan PT Internasional Nickel Indonesia (PT INCO), di Soroako, Sulawesi Tengah dengan produksi nickel matte \pm 70.000 ton (Swamidharma, 2011).

\section{Pengembangan Kawasan Pertambangan Nikel}

Di wilayah Pulau Sulawesi juga terdapat empat lokasi penting yang memiliki cadangan nikel melimpah untuk pengembangan kawasan pertambangan nikel, yakni: Soroako, Kabupaten Luwu Timur, Sulawesi Selatan; Kabupaten Morowali, Sulawesi Tengah; Pomalaa, Kabupaten Kolaka, dan Kabupaten Konawe, 
Sulawesi Tenggara (Anonim, 2011a). Selain itu juga terdapat pusat kawasan pertambangan dan pengolahan mineral logam di Pulau Sulawesi, yakni: Penambangan dan pengolahan serta pemurnian nikel di Konawe Utara, Morowali, Soroako, dan Pomalaa; tambang dan pabrik Nickel Pig Iron di Bahodopi dan Konawe; serta Pembangunan pabrik Ferro Nickel di Kolaka, Kolaka Utara dan Konawe Utara (Anonim, 2011a).

Oleh karena itu dalam rangka pengembangan kawasan pertambangan nikel di Sulawesi Tenggara, perlu dilakukan penentuan kawasan andalan pertambangan berbasis sektor unggulan sumber daya nikel pada Kabupaten Konawe dan Kabupaten Konawe Utara. Analisis kawasan andalan dilakukan dengan pendekatan konsep SGW (Hirnawan, 2005).
Metoda analisis yang dilakukan meliputi: analisis SGW; analisis valuasi holistik SGW (skoring dan pembobotan) dan penentuan skala prioritas pengembangan kawasan pertambangan. Analisis ini dititikberatkan pada formasi batuan pembawa logam nikel berdasarkan peta geologi daerah penelitian (Moetamar, 2007).

Satuan Genetika Wilayah (SGW) atau Terrain Genetic Unit adalah suatu sistem yang dibentuk oleh sifat-sifat bawaan kewilayahan atau unit-unit pembentuk karakteristik wilayah yang menentukan potensi dan kendala wilayah yang bersangkutan. Satuan genetika wilayah merupakan konsep untuk mempersatukan berbagai sifat atau faktor genetik pembentuk wilayah untuk memetakan karakterisasi, potensi dan kendala wilayah secara terukur dan komprehensif. Karakteristik wilayah

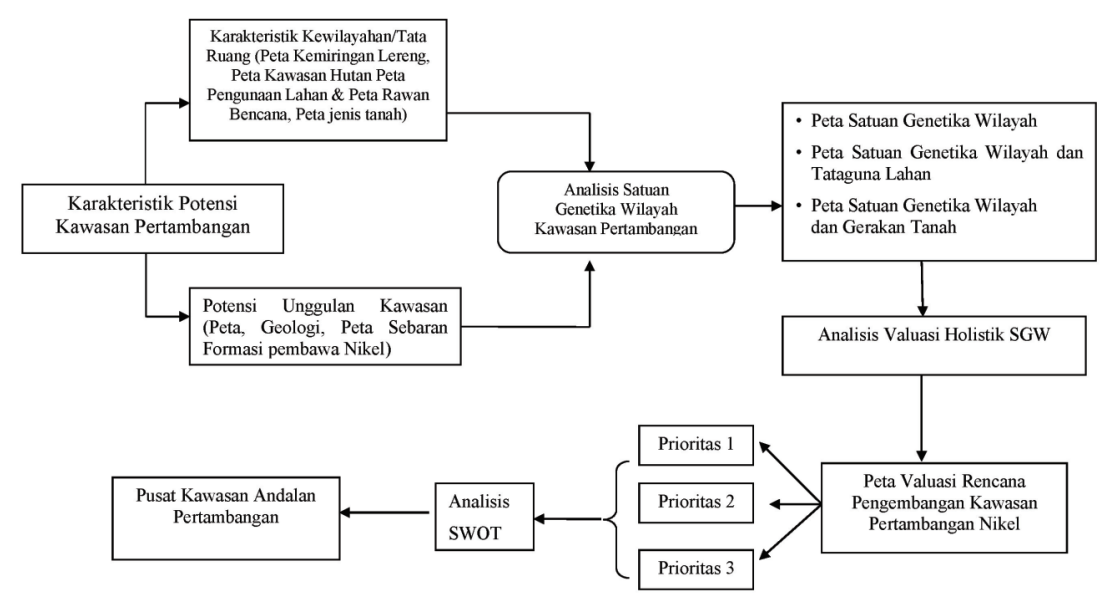

Gambar 3. Alur pikir untuk penentuan kawasan pertambangan

Tujuan penelitian ini untuk menentukan skala prioritas wilayah untuk pengembangan kawasan pertambangan dan menentukan wilayah yang layak dikembangkan sebagai kawasan andalan pertambangan nikel, dengan pendekatan konsep SGW untuk menentukan karakteristik pada tiap-tiap satuan genetika wilayah yang dititikberatkan pada formasi pembawa logam (nikel).

\section{METODA}

Metoda analisis dalam tulisan ini dituangkan dalam alur pikir deduksi, seperti terlihat dalam gambar 3 , sesuai langkah-langkah penelitian dedukto $=>$ hipotetiko $=>$ verifikatif (Hirnawan, 2009). adalah sejumlah sifat-sifat kewilayahan yang menentukan potensi dan kendala yang bersangkutan (Hirnawan, 2005).

Genetika wilayah terbentuk berdasarkan tiga unsur genetika, yang dikenali sebagai penentu asal-usul kejadian wilayah yang dipetakan, yakni: klasifikasi litologi-tektonikmorfologi (Hirnawan, 2005). Ketiga unsur ini merupakan unit-unit wilayah terkecil yang mempunyai kesamaan genetika dan karakteristik, potensi dan kendala yang sama (homogen). Unit-unit wilayah ini merupakan satuan peta dari Peta Genetika Wilayah (Tabel 1).

Dalam analisis data spasial digunakan teknologi Sistem Informasi Geografis untuk meningkatkan ketelitian pemetaan SGW, serta permodelan dalam 
proses pendelineasian skala prioritas kawasan pertambangan. Pada metoda analisis spasial dilakukan analisis fisik dengan metoda tumpang susun (overlay), dengan teknik splitting (pemisahan), dan buffering (penyanggaan) terhadap berbagai obyek peta yang ada dengan menggunakan metode Operasi Boolean (I Wayan, 2004). tersebut digunakan dalam per-timbangan untuk pembobotan dalam analisis valuasi holistik SGW.

Analisis valuasi holistik SGW ini merupakan kelanjutan tahap analisis SGW, dengan melakukan penilaian, pembobotan dengan menggunakan Matrik Holistik SGW atau matriks keserbacakupan aspek

Tabel 1.

Jenis-jenis SGW

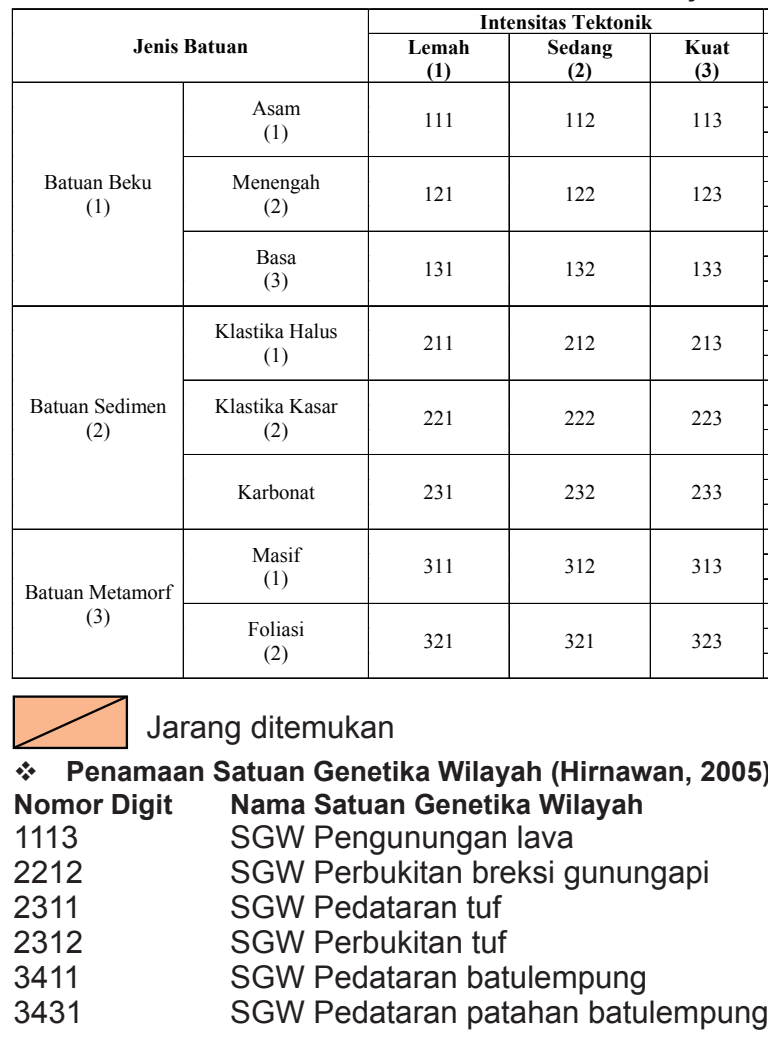

Dalam analisis ini dilakukan overlay peta formasi batuan pembawa mineral logam, peta geologi khususnya dan peta kemiringan lereng (morfologi) yang telah diproses dengan teknik spliting untuk pembuatan peta Satuan Genetika Wilayah. Selanjutnya dilakukan overlay terhadap peta jalan dan peta sungai dengan teknik buffering, untuk membatasi bahwa kegiatan penambangan mineral tidak terletak di Kawasan Sempadan Sungai dan jalan (Anonim, 2011c).

Selanjutnya dilakukan tumpang susun peta SGW dengan peta tataguna lahan, peta rawan bencana gempa bumi, peta rawan bencana gerakan tanah dengan proses teknik splitting untuk diperoleh Peta Satuan Genetika Wilayah dan Tataguna Lahan serta Peta Satuan Genetika Wilayah dan Zona Rawan Bencana. Peta-peta karakteristik wilayah (Hirnawan, 2005). Dalam valuasi ini dilakukan analisis hanya terhadap 4 faktor atau 20 sub faktor dari tiaptiap unit SGW dengan kontribusi pembobotan (dimodifikasi dari Hirnawan, 2005), sebagai berikut (Tabel 2):

1) keekonomian bahan tambang (40\%),

2) keekonomian kewilayahan tataruang $(40 \%)$,

3) stabilitas fisik wilayah (10\%)

4) ancaman resiko / bencana alam (10\%),

Proporsi kontribusi pembobotan dengan perbandingan $4: 4: 2$, perbandingan faktor pengembangan sumber daya mineral (40\%): kewilayahan (40\%): lingkungan $(20 \%)$ diarahkan untuk analisis pengembangan kawasan pertambangan berbasis keekonomian sumber daya mineral. (20\% dimodifikasi dari Hirnawan, 2005). 
Tabel 2.

Kontribusi Bobot dan Nilai faktor dan sub faktor Valuasi SGW

\begin{tabular}{|c|c|c|c|c|c|}
\hline \multirow[t]{3}{*}{ NO. } & \multirow{3}{*}{ FAKTOR } & \multirow{3}{*}{$\begin{array}{l}\text { Bobot } \\
\text { Faktor }\end{array}$} & \multirow{3}{*}{ SUB FAKTOR } & \multirow{2}{*}{\multicolumn{2}{|c|}{$\begin{array}{c}\text { BOBOT } \\
\text { SUB FAKTOR }\end{array}$}} \\
\hline & & & & & \\
\hline & & & & Kajian & Global \\
\hline \multirow[t]{6}{*}{1} & \multirow{6}{*}{$\begin{array}{l}\text { Keekonomian } \\
\text { bahan galian } \\
\text { /tambang }\end{array}$} & \multirow[t]{6}{*}{40} & Cadangan/sumber daya & 30 & 12.00 \\
\hline & & & Kualitas & 20 & 8.00 \\
\hline & & & Pangsa Pasar/Status IUP & 30 & 12.00 \\
\hline & & & Tempat Simpan Tanahpucuk & 10 & 4.00 \\
\hline & & & Tingkat Kesulitan Pengerjaan & 10 & 4.00 \\
\hline & & & Sub Total & 100 & 40.00 \\
\hline \multirow[t]{8}{*}{2} & \multirow{8}{*}{$\begin{array}{l}\text { Ke ekonomian } \\
\text { Wilayah } \\
\text { Ruang }\end{array}$} & \multirow[t]{8}{*}{40} & Kemiringan lereng & 20 & 8.00 \\
\hline & & & Tutupan Lahan/Status Hutan & 30 & 12.00 \\
\hline & & & Infrastruktur jalan/Aksesibilitas & 15 & 6.00 \\
\hline & & & Infrastruktur pelabuhan & 10 & 4.00 \\
\hline & & & Kesediaan Air/sungai & 10 & 4.00 \\
\hline & & & Ketersedian Bahan Bangunan & 10 & 4.00 \\
\hline & & & Areal Buangan Limbah & 5 & 2.00 \\
\hline & & & & 100 & 40.00 \\
\hline \multirow[t]{4}{*}{3} & \multirow{4}{*}{$\begin{array}{l}\text { Stabilitas } \\
\text { Kewilayahan } \\
\text { Tata Ruang }\end{array}$} & \multirow[t]{4}{*}{10} & Lereng Alamiah & 40 & 4.00 \\
\hline & & & Permukaan Tanah/Jenis Tanah & 30 & 3.00 \\
\hline & & & Goncangan/Percepatan Gempa & 30 & 3.00 \\
\hline & & & & 100 & 10.00 \\
\hline \multirow[t]{7}{*}{4} & \multirow{6}{*}{$\begin{array}{l}\text { Ancaman } \\
\text { Resiko/Bencana } \\
\text { Alam }\end{array}$} & \multirow[t]{6}{*}{10} & Gerakan Tanah & 30 & 3.00 \\
\hline & & & Gempa Bumi & 20 & 2.00 \\
\hline & & & Erupsi Gunung Api & 15 & 1.50 \\
\hline & & & $\begin{array}{l}\text { Nendatan Tektonik/zona } \\
\text { seismo tektonik/ longsoran }\end{array}$ & 20 & 2.00 \\
\hline & & & Banjir & 15 & 1.50 \\
\hline & & & $\begin{array}{r}\text { Sub Total } \\
\end{array}$ & 100 & 10.00 \\
\hline & & 100 & Jumlah Global & & 100.00 \\
\hline
\end{tabular}

(modifikasi dari Hirnawan, 2005)

Tabel 3.

Kriteria Penilaian Sub Faktor Karakteristik wilayah

\begin{tabular}{|c|l|l|}
\hline \multicolumn{2}{|c|}{ Nilai } & Keterangan \\
\hline 3 & A & Sangat Baik \\
\hline 2 & B & Baik \\
\hline 1 & C & Cukup \\
\hline 0 & N & Bila tidak ditambang \\
\hline-1 & c & Kurang \\
\hline-2 & b & SangatKurang \\
\hline-3 & a & Sangat kurang sekali \\
\hline
\end{tabular}

(Hirnawan, 2005)

Setiap sub faktor berturut-turut mempunyai nilai (skoring) seperti pada tabel 3. Hasil proporsi kontribusi pembobotan ini digunakan untuk analisis valuasi dengan menggunakan Matrik holistik (tabel 4) (dimodifikasi dari Hirnawan, 2005).

Nilai potensi wilayah dikelompokkan untuk penentuan skala prioritas pengembangan kawasan pertambangan didasarkan pada nilai SGW skenario dikembangkan/ditambang, yakni:

a. potensi tinggi : $200-300$ (prioritas 1/sangat layak dikembangkan).

b. potensi menengah: $100 \mathrm{~s} / \mathrm{d} 200$ (prioritas 2/layak-cukup layak dikembangkan).

c. potensi rendah : $0 \mathrm{~s} / \mathrm{d} 100$ (prioritas 3/tidak layak dikembangkan).

Penentuan kawasan andalan pertambangan ditentukan dari analisis terkait faktor Strenght, Weakness, Opportunity dan Threat (SWOT) dan verifikasi karakteristik kewilayahan terhadap nilai valuasi holistik dari SGW yang memiliki potensi tinggi nilai untuk dikembangkan (>200) terhadap faktor keekonomian bahan tambang, keekonomian wilayah tataruang, potensi energi, aspek kebencanaan alam serta kebijakan dan kependudukan. 


\section{HASILDAN PEMBAHASAN}

Hasil analisis spasial dari peta potensi dan sebaran formasi batuan pembawa nikel, peta geologi dan peta kemiringan lereng di Kabupaten Konawe dan Kabupaten Konawe Utara, maka diperoleh "Peta Satuan Genetika Wilayah", pada formasi batuan pembawa nikel untuk kedua kabupaten. Peta Satuan Genetika ini dapat dibagi atas 4 unit SGW, yakni:

1. SGW Pedataran Batuan Ultramafik (1311)

2. SGW Pedataran Patahan Batuan Ultramafik (1331)

3. SGW Perbukitan Batuan Ultramafik (1312)

4. SGW Perbukitan Patahan Batuan Ultramafik (1332)

Selanjutnya diperoleh Peta Satuan Genetika Wilayah dan Tataguna Lahan serta Peta Satuan Genetika Wilayah dan Bencana Gerakan Tanah untuk kedua kabupaten. Peta Satuan Genetika Wilayah dan Tataguna Lahan pada Kabupaten Konawe, disajikan pada gambar 4 .

Sesuai hasil analisis valuasi matrik holistik SGW (tabel 4), diperoleh nilai valuasi SGW skenario ditambang /dikembangkan dan skenario exsisting /tidak ditambang untuk tiap-tiap SGW dari kedua kabupaten. Pada Kabupaten Konawe diperoleh sebanyak 204 nilai valuasi SGW dan untuk Kabupaten Konawe Utara diperoleh 248 nilai valuasi SGW.

Di Kabupaten Konawe terdapat nilai valuasi skenario ditambang berpotensi terendah +76 , yang dijumpai pada SGW Perbukitan Batuan Ultramafik daerah Puriala (tabel 4). Nilai valuasi skenario ditambang berpotensi tertinggi +265 terdapat pada SGW Perbukitan Batuan Ultramafik daerah Pondidaha.

Di Kabupaten Konawe Utara nilai valuasi skenario ditambang berpotensi terendah +56 yang dijumpai pada SGW Perbukitan Patahan Batuan.Pada Ultramafik daerah Asera nilai valuasi skenario ditambang berpotensi tertinggi +298 , pada SGW Pedataran Batuan Ultramafik Molawe (tabel 7).

Selanjutnya dari Peta Valuasi Satuan Genetika Wilayah Kawasan Pertambangan Nikel, maka diperoleh 3 (tiga) skala prioritas pengembangan kawasan pertambangan nikel, yakni(Gambar 5): a. prioritas III, berpotensi rendah dikembangkan /ditambang (nilai valuasi SGW < 100); b. prioritas II, berpotensi menengah dikembangkan/ditambang (nilai valuasi SGW 100 s/d 200), c. prioritas I, berpotensi tinggi dikembangkan/ditambang (nilai valuasi SGW > 200). Adapun nilai valuasi SGW prioritas I (berpotensi tinggi) pada Kabupaten Konawe dan Kabupaten Konawe Utara, yang disajikan pada tabel 5 tabel 6 .

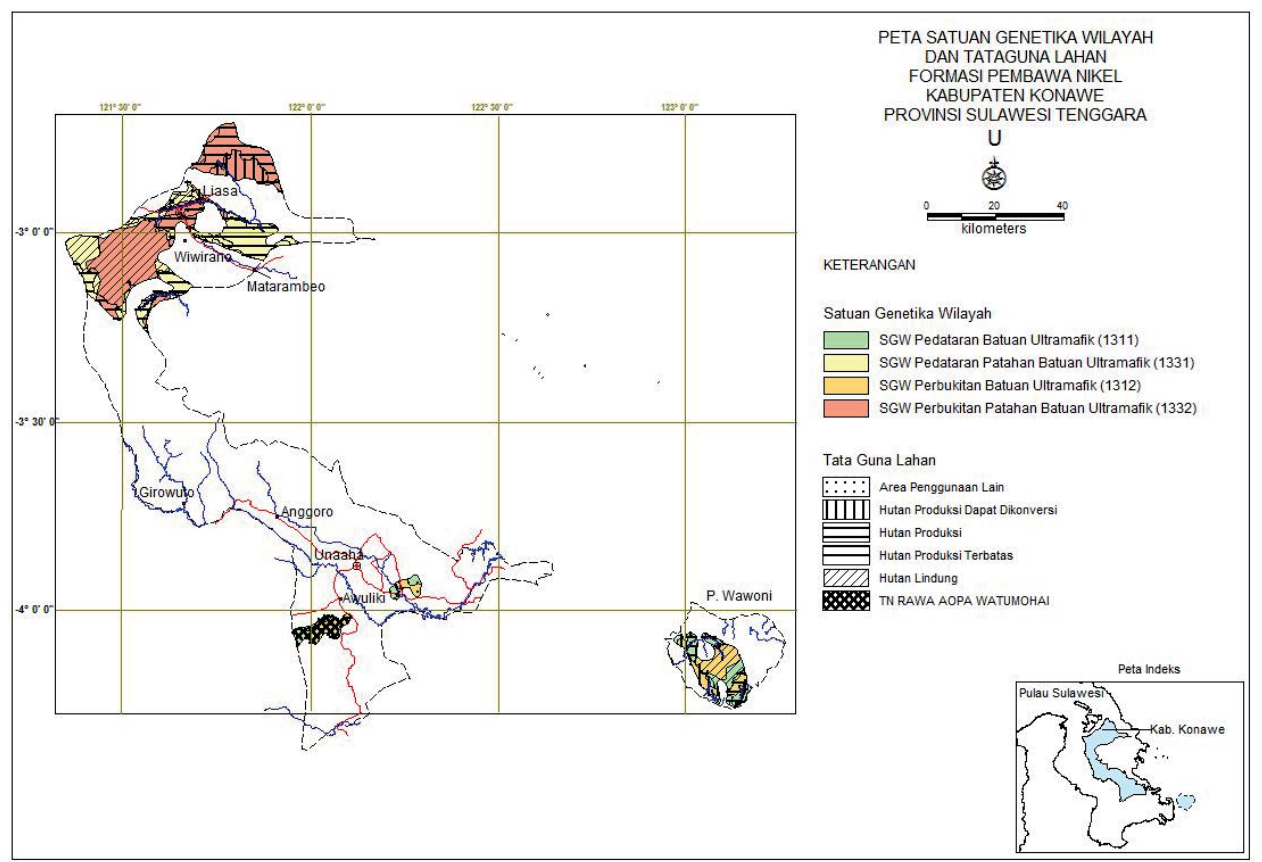

Gambar 4. Peta Satuan Genetika Wilayah dan Tataguna Lahan Kabupaten Konawe 


\section{PEMBAHASAN}

Dari hasil valuasi matrik holistik SGW tersebut, maka diperoleh keterkaitan nilai potensi dan kendala wilayah dari unit-unit karakteritik wilayah terhadap total nilai valuasi dari tiap-tiap SGW. Hubungan keterkaitan nilai karakteritik wilayah terhadap nilai valuasi SGW tersebut dapat disajkan pada tabel 4 dan tabel 7, yakni:

Nilai valuasi matriks holistik SGW Pedataran Batuan Ultramafik di daerah Puriala kabupaten Konawe (tabel 4), menunjukan nilai total skenario ditambang sebesar +76, dan nilai kondisi tidak ditambang sebesar +90 . Hal ini menunjukkan nilai keekonomian wilayah berpotensi rendah untuk dikembangkan /ditambang dan nilai skenario ditambang lebih kecil dari kondisi tidak ditambang.
Total nilai valuasi SGW tersebut, terutama dipengaruhi oleh nilai faktor keekonomian bahan tambang +112 , yang menunjukkan nilai potensi wilayah. Dan nilai faktor keekonomian wilayah tata ruang -26 , yang menunjukkan nilai kendala wilayah, yakni berada pada Taman Nasional. Dengan demikian, SGW Pedataran Batuan Ultramafik daerah Puriala ini tidak layak dikembangkan sebagai kawasan pertambangan nikel.

Pada nilai valuasi holistik pada SGW Pedataran Batuan Ultramafik Kecamatan Molawe Kab Konawe Utara (tabel 7) diperoleh total nilai valuasi SGW dikembangkan/ditambang sebesar +298, dan nilai kondisi tidak ditambang/existing sebesar +282. Hal ini menunjukkan nilai keekonomian wilayah berpotensi tertinggi. Sehingga SGW ini layak dikembangkan sebagai kawasan pertambangan nikel.

Tabel 4.

Matriks Holistik SGW Pedataran Batuan Ultramafik Kecamatan Puriala - Konawe

\begin{tabular}{|c|c|c|c|c|c|c|c|c|c|c|c|c|c|c|c|}
\hline \multirow[t]{3}{*}{ No. } & \multirow[t]{3}{*}{ FAKTOR } & \multirow{3}{*}{$\begin{array}{c}\text { BOBOT } \\
\text { FAKTOR }\end{array}$} & \multirow[t]{3}{*}{ SUB FAKTOR } & \multirow{2}{*}{\multicolumn{2}{|c|}{\begin{tabular}{|c|} 
BOBOT \\
SUB FAKTOR \\
\end{tabular}}} & \multirow{2}{*}{\multicolumn{2}{|c|}{$\begin{array}{c}\text { N I } \\
\text { Ditambang }\end{array}$}} & \multirow{2}{*}{\multicolumn{2}{|c|}{$\begin{array}{l}\text { L A } \quad \text { I } \\
\text { Tidak itambang }\end{array}$}} & \multicolumn{6}{|c|}{ B O B O T \& NILAI } \\
\hline & & & & & & & & & & \multicolumn{3}{|c|}{ Ditambang } & \multicolumn{3}{|c|}{ Tidak Ditambang } \\
\hline & & & & Kajian & Global & \begin{tabular}{|l|} 
On \\
Site \\
\end{tabular} & $\begin{array}{l}\text { Off } \\
\text { Site }\end{array}$ & $\begin{array}{l}\text { On } \\
\text { Site } \\
\end{array}$ & Off Site & $\begin{array}{l}\text { On } \\
\text { Site } \\
\end{array}$ & $\begin{array}{l}\text { Off } \\
\text { Site } \\
\end{array}$ & Total & $\begin{array}{l}\text { On } \\
\text { Site } \\
\end{array}$ & \begin{tabular}{|l|} 
Off \\
Site \\
\end{tabular} & Total \\
\hline \multirow[t]{6}{*}{1} & \multirow{6}{*}{$\begin{array}{l}\text { Keekonomian } \\
\text { Bahan Tambang }\end{array}$} & \multirow[t]{6}{*}{40} & Cadangan/sumber daya & 30 & 12.00 & $\mathrm{C}$ & $\mathrm{C}$ & $\mathrm{C}$ & $\mathrm{C}$ & 12 & 12 & 24 & 12 & 12 & 24 \\
\hline & & & Kualitas & 20 & 8.00 & B & B & B & B & 16 & 16 & 32 & 16 & 16 & 32 \\
\hline & & & Pangsa Pasar/Status IUP & 30 & 12.00 & $\mathrm{C}$ & $\mathrm{C}$ & $\mathrm{C}$ & $\mathrm{C}$ & 12 & 12 & 24 & 12 & 12 & 24 \\
\hline & & & Tmpt Simpn Tanahpucuk & 10 & 4.00 & $\mathrm{~B}$ & $\mathrm{~B}$ & $\mathrm{~B}$ & $\mathrm{~B}$ & 8 & 8 & 16 & 8 & 8 & 16 \\
\hline & & & Tgkt Kesulitn Pengerjaan & 10 & 4.00 & $\mathrm{~B}$ & $\mathrm{~B}$ & $\mathrm{~B}$ & $\mathrm{~B}$ & 8 & 8 & 16 & 8 & 8 & 16 \\
\hline & & & & 100 & 40.00 & \multicolumn{4}{|r|}{ Subtotal } & 56.0 & 56.0 & 112.0 & 56.0 & 56.0 & 112.0 \\
\hline \multirow[t]{8}{*}{2} & \multirow{8}{*}{$\begin{array}{l}\text { Keekonomian } \\
\text { Wilayah Tata } \\
\text { Ruang }\end{array}$} & \multirow[t]{8}{*}{40} & Kemiringan lereng & 20 & 8.00 & $\mathrm{~B}$ & $\mathrm{~b}$ & $\mathrm{~B}$ & $\mathrm{~b}$ & 16 & -16 & 0 & 16 & -16 & 0 \\
\hline & & & Tutupan Lahan/Status Hutan & 30 & 12.00 & $\mathrm{~b}$ & $\mathrm{~b}$ & $\mathrm{~b}$ & $\mathrm{~b}$ & -24 & -24 & -48 & -24 & -24 & -48 \\
\hline & & & \begin{tabular}{|l|} 
Aksesibilitas/Infrastruktur jalan \\
\end{tabular} & 15 & 6.00 & $\mathrm{C}$ & $\mathrm{B}$ & $\mathrm{B}$ & $\mathrm{B}$ & 6 & 12 & 18 & 12 & 12 & 24 \\
\hline & & & Infrastruktur pelabuhan & 10 & 4.00 & $\mathrm{C}$ & $\mathrm{C}$ & $\mathrm{C}$ & $\mathrm{C}$ & 4 & 4 & 8 & 4 & 4 & 8 \\
\hline & & & Kesediaan Air & 10 & 4.00 & $\mathrm{C}$ & $\mathrm{C}$ & $\mathrm{B}$ & $\mathrm{B}$ & 4 & 4 & 8 & 8 & 8 & 16 \\
\hline & & & Ktersdian Bhn Bangunan & 10 & 4.00 & $\mathrm{c}$ & $\mathrm{c}$ & $\mathrm{c}$ & $\mathrm{c}$ & -4 & -4 & -8 & -4 & -4 & -8 \\
\hline & & & Areal Buangan Limbah & 5 & 2.00 & $\mathrm{c}$ & $\mathrm{c}$ & $\mathrm{c}$ & $\mathrm{N}$ & -2 & -2 & -4 & -2 & -2 & -4 \\
\hline & & & & 100 & 40.00 & \multicolumn{4}{|r|}{ Subtotal } & -32.0 & 6.0 & -26.0 & -22.0 & 10.0 & -12.0 \\
\hline \multirow[t]{4}{*}{3} & \multirow{4}{*}{$\begin{array}{l}\text { Stabilitas } \\
\text { Kewilayahan } \\
\text { Tata Ruang }\end{array}$} & \multirow[t]{4}{*}{10} & Lereng Alamiah & 40 & 4.00 & $\mathrm{~B}$ & $\mathrm{~b}$ & $\mathrm{~B}$ & $\mathrm{~b}$ & 8 & -8 & 0 & 8 & -8 & 0 \\
\hline & & & Permukaan Tanah/jenis tanah & 30 & 3.00 & $\mathrm{~B}$ & $\mathrm{~N}$ & $\mathrm{~B}$ & $\mathrm{~N}$ & 6 & 0 & 6 & 6 & 0 & 6 \\
\hline & & & Goncangan/Percepatan Gempa & 30 & 3.00 & $\mathrm{c}$ & $\mathrm{c}$ & $\mathrm{c}$ & $\mathrm{c}$ & -3 & -3 & -6 & -3 & -3 & -6 \\
\hline & & & & 100 & 10.00 & & & & Subtotal & -5.0 & 5.0 & 6.0 & -5.0 & 8.0 & 6.0 \\
\hline \multirow[t]{6}{*}{4} & \multirow{6}{*}{$\begin{array}{l}\text { Acaman risiko } \\
\text { Bencana } \\
\text { Alam }\end{array}$} & \multirow[t]{6}{*}{10} & Gerakan tanah & 30 & 3.00 & $\mathrm{c}$ & $\mathrm{c}$ & $\mathrm{c}$ & $\mathrm{c}$ & -3 & -3 & -6 & -3 & -3 & -6 \\
\hline & & & \multirow{5}{*}{$\begin{array}{l}\text { Gempa bumi } \\
\text { Erupsi Gunung Api } \\
\text { Nendatan tektonik/ seismotekto- } \\
\text { nik/Longsoran } \\
\text { Banjir }\end{array}$} & 20 & 2.00 & $\mathrm{c}$ & $\mathrm{c}$ & $\mathrm{c}$ & $\mathrm{c}$ & -2 & -2 & -4 & -2 & -2 & -4 \\
\hline & & & & 15 & 1.50 & $\mathrm{~N}$ & $\mathrm{~N}$ & $\mathrm{~N}$ & $\mathrm{~N}$ & 0 & 0 & 0 & 0 & 0 & 0 \\
\hline & & & & 15 & 1.50 & $\mathrm{c}$ & $\mathrm{c}$ & $\mathrm{c}$ & $\mathrm{c}$ & -3 & -3 & -6 & -3 & -3 & -6 \\
\hline & & & & 20 & 2.00 & $\mathrm{~N}$ & $\mathrm{~N}$ & $\mathrm{~N}$ & $\mathrm{~N}$ & 0 & 0 & 0 & 0 & 0 & 0 \\
\hline & & & & 100 & 10 & & & & Subtotal & -8 & -8 & -16 & -8 & -8 & -16 \\
\hline \multicolumn{2}{|c|}{ Jumlah Global } & 100 & & & 100 & & & & Total & 11.00 & 59.00 & 76.00 & 21.00 & 66.00 & 90.00 \\
\hline
\end{tabular}

Tabel 5.

Rekapitulasi Daerah SGW Berpotensi Tinggi (Priortas I) untuk Pengembangan Kawasan Pertambangan Kab, Konawe

\begin{tabular}{|l|l|l|r|c|c|}
\hline No & $\begin{array}{l}\text { Satuan Genetika } \\
\text { Wilayah }\end{array}$ & Kecamatan & $\begin{array}{c}\text { sumber daya } \\
\text { (juta ton) }\end{array}$ & $\begin{array}{c}\text { Tataguna } \\
\text { lahan }\end{array}$ & $\begin{array}{c}\text { Nilai skenario } \\
\text { ditambang }\end{array}$ \\
\hline 1 & $\begin{array}{l}\text { Pedataran Batuan } \\
\text { Ultramafik }\end{array}$ & Pondidaha & 2,35 & APL & $232-265$ \\
\hline 2 & $\begin{array}{l}\text { Pedataran Patahan } \\
\text { Batuan Ultramafik }\end{array}$ & Routa & 214,72 & $\begin{array}{c}\text { APL, HP, } \\
\text { dan HL }\end{array}$ & $206-235$ \\
\hline 3 & $\begin{array}{l}\text { PerbukitanBatuan } \\
\text { Ultramafik }\end{array}$ & Pondidaha & 2,45 & APL, HP & $211-265$ \\
\hline 4 & $\begin{array}{l}\text { Perbukitan } \\
\text { Patahan Batuan } \\
\text { Ultramafik }\end{array}$ & Routa & 32,31 & APL, HP & $208-240$ \\
\hline
\end{tabular}


Tabel 6.

Rekapitulasi Daerah SGW Yang Berpotensi Tinggi (Priortas I) Untuk Pengembangan Kawasan Pertambangan Kab, Konawe Utara

\begin{tabular}{|c|c|c|c|c|c|}
\hline No & $\begin{array}{c}\text { Satuan Genetika } \\
\text { Wilayah }\end{array}$ & Kecamatan & $\begin{array}{c}\text { Sumber daya } \\
\text { (jutaton) }\end{array}$ & Tataguna lahan & $\begin{array}{c}\text { Nilai } \\
\text { skenario } \\
\text { ditambang }\end{array}$ \\
\hline \multirow[t]{5}{*}{1} & \multirow{5}{*}{$\begin{array}{l}\text { Pedataran Batuan } \\
\text { Ultramafik }\end{array}$} & Andowia & 77,42 & APL, HP & $200-266$ \\
\hline & & Asera & 20,38 & $\begin{array}{l}\text { APL,HPK,HP, } \\
\text { HPT }\end{array}$ & $204-282$ \\
\hline & & Molawe & 157,19 & APL, HP, HL & $200-298$ \\
\hline & & Oheo & 11,18 & APl, HPK, HP & 204- 234 \\
\hline & & Wiwirano & 34,22 & HPK, HP & $210-264$ \\
\hline \multirow[t]{4}{*}{2} & \multirow{4}{*}{$\begin{array}{l}\text { Pedataran Patahan } \\
\text { Batuan Ultramafik }\end{array}$} & Wiwirano & 28,82 & HPK, HPT & $215-252$ \\
\hline & & Andowia & 4,22 & APL & $252-284$ \\
\hline & & Asera & 38,73 & APL & $212-242$ \\
\hline & & Langikima & $1.147,56$ & HPK, HP, HPT & $204-264$ \\
\hline \multirow[t]{3}{*}{3} & \multirow{3}{*}{$\begin{array}{l}\text { Perbukitan Batuan } \\
\text { Ultramafik }\end{array}$} & Langikima & 35,14 & HL, HP & $212-244$ \\
\hline & & Asera & 31,43 & HPK & 216 \\
\hline & & Molawe & 48,89 & APL, HP & $204-272$ \\
\hline \multirow[t]{3}{*}{4} & \multirow{3}{*}{$\begin{array}{l}\text { Perbukitan } \\
\text { Patahan Batuan } \\
\text { Ultramafik }\end{array}$} & Molawe & 40,29 & APL & 286 \\
\hline & & Asera & 58,57 & APL & 264 \\
\hline & & Andowia & 12,16 & APL, HP, HPT, HL & $202-256$ \\
\hline
\end{tabular}

Nilai valuasi ini didukung oleh nilai faktor keekonomian potensi bahan tambang +184 , dan nilai faktor keekonomian wilayah tataruang sebesar + 136. Hal ini didukung oleh sub faktor tataguna lahan/status hutan yang termasuk pada kawasan Area Pengunaan Lainnya (APL).

Sesuai Peta valuasi Satuan Genetika Wilayah Kawasan Pertambangan Nikel Kabupaten Konawe dan Konawe Utara (gambar 5) dan nilai valuasi SGW, maka diperoleh 12 wilayah pada 4 SGW, yang berpotensi tinggi (nilai valuasi SGW> 200, prioritas I) untuk dikembangkan sebagai kawasan pertambangan nikel, yakni :
Kabupaten Konawe: SGW pedataran patahan batuan ultramafik Routa, RoutaLiasa, Routa-Wiwirano; SGW perbukitan patahan batuan ultramafik Routa-Liasa dan Routa-Sampala; SGW pedataran batuan ultramafik dan SGW perbukitan batuan ultramafik daerah Pondidaha. Dan Kabupaten Konawe Utara: SGW pedataran batuan ultramafik daerah Asera, Oheo, Andowia dan Molawe; SGW pedataran patahan Batuan Ultramafik daerah Andowia, Wiwirano, Langikima; SGW Perbukitan batuan ultramafik Molawe; dan SGW Perbukitan patahan batuan ultramafik Molawe.

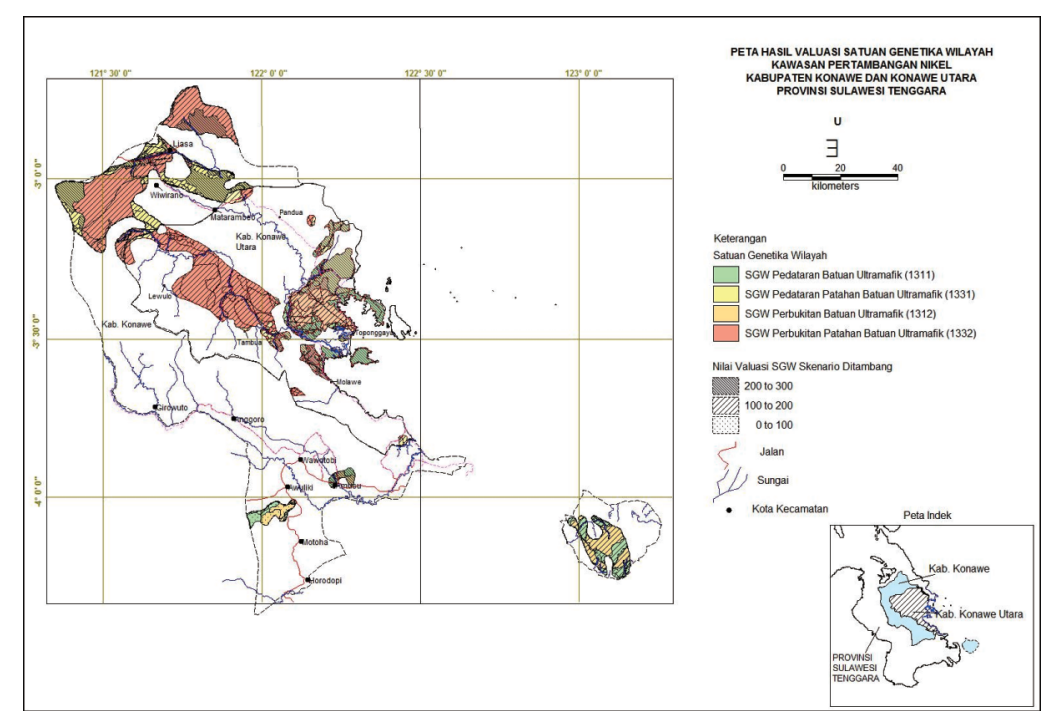

Gambar 5. Peta Valuasi SGW Kawasan Pertambangan Nikel Kabupaten Konawe dan Konawe Utara 
Tabel 7.

Rekapitulasi Matriks Holistik SGW Pedataran Batuan Ultramafik Kecamatan Molawe - Konawe Utara

\begin{tabular}{|c|l|c|c|c|c|c|c|}
\hline \multirow{2}{*}{ NO. } & \multicolumn{1}{|c|}{ FAKTOR } & \multicolumn{3}{|c|}{ DITAMBANG } & \multicolumn{3}{c|}{ TIDAK DITAMBANG } \\
\cline { 2 - 8 } & \multicolumn{1}{|c|}{ On Site } & Off Site & Total & On Site & Off Site & Total \\
\hline 1 & $\begin{array}{l}\text { Keekonomian } \\
\text { Bahan Tambang }\end{array}$ & $\mathbf{9 2 . 0}$ & $\mathbf{9 2 . 0}$ & $\mathbf{1 8 4 . 0}$ & $\mathbf{9 2 . 0}$ & $\mathbf{9 2 . 0}$ & $\mathbf{1 8 4 . 0}$ \\
\hline 2 & $\begin{array}{l}\text { Keekonomian } \\
\text { Wilayah Tataruang }\end{array}$ & $\mathbf{8 8 . 0}$ & $\mathbf{4 8 . 0}$ & $\mathbf{1 3 6 . 0}$ & $\mathbf{7 8 . 0}$ & $\mathbf{4 2 . 0}$ & $\mathbf{1 2 0 . 0}$ \\
\hline 3 & $\begin{array}{l}\text { Stabilitas } \\
\text { Kewilayahan } \\
\text { tataruang }\end{array}$ & $\mathbf{6 . 0}$ & $\mathbf{- 1 4 . 0}$ & $\mathbf{- 8 . 0}$ & $\mathbf{6 . 0}$ & $\mathbf{- 1 4 . 0}$ & $\mathbf{- 8 . 0}$ \\
\hline 4 & $\begin{array}{l}\text { Acaman risiko } \\
\text { Bencana Alam }\end{array}$ & $\mathbf{- 7}$ & $\mathbf{- 7}$ & $\mathbf{- 1 4}$ & $\mathbf{- 7}$ & $\mathbf{- 7}$ & $\mathbf{- 1 4}$ \\
\hline \multicolumn{2}{|l|}{ Total } & $\mathbf{1 7 9 . 0 0}$ & $\mathbf{1 1 9 . 0 0}$ & $\mathbf{2 9 8 . 0 0}$ & $\mathbf{1 6 9 . 0 0}$ & $\mathbf{1 1 3 . 0 0}$ & $\mathbf{2 8 2 . 0 0}$ \\
\hline
\end{tabular}

Sesuai verifikasi kondisi fisik dan infrastruktur kawasan pertambangan daerah Puriala, Konawe terletak pada kawasan TamanNasional dan jalan memadai, dengan nilai valuasi skenario dikembangkan +76 termasuk nilai keekonomian wilayah berpotensi rendah dikembangkan (gambar 6). Dan sesuai verifikasi di daerah kawasan pertambangan Langikima (PT Startage), diperoleh gambaran merupakan daerah penambangan yang telah status IUP produksi (gambar 7), termasuk SGW pedataran patahan batuan ultramafik, jalan memadai, infrastruktur pelabuhan tersedia, dengan nilai valuasi 248 , berpotensi tinggi dikembangkan sebagai kawasan pertambangan.

Selanjutnya untuk menentukan kawasan andalan pertambangan nikel dapat dilakukan dengan analsisi matriks SWOT yang dittikberatkan pada wilayah SGW pedataran, dengan morfologi pedataran landai dan pedataran plato merupakan daerah yang prospek untuk endapan nikel
(Chetetat, 1947 dan Swamidharma, 2011). Sesuai evaluasi faktor keekonomian potensi bahan galian, keekonomian wilayah tataruang dan kebencanaan alam, diperoleh delapan daerah pada kedua kabupaten ini, yang berpotensi tinggi untuk dipertimbangkan sebagai kawasan andalan pertambangan nikel (tabel 8).

Sesuai analisis matriks SWOT (Tabel 9), dan nilai valuasi SGW pada kawasan pertambangan ini, maka direkomendasikan Kawasan Andowia-Asera-Molawe dan Langikima Kabupaten Konawe Utara memiliki peluang tertinggi untuk dikembangkan sebagai pusat Kawasan Andalan Pertambangan Nikel (gambar 8), dengan total sumber daya 1,14 Milyar Ton, status IUP Operasi-produksi, yang didukung infrastruktur jalan memadai dan pelabuhan tersedia-memungkinkan dibangun. Untuk pengembangan kawasan ini dilakukan langkah strategi seperti pada strategis perbandingan Strengh-Opportunity (S-O) pada matrik analisis SWOT (tabel 9).

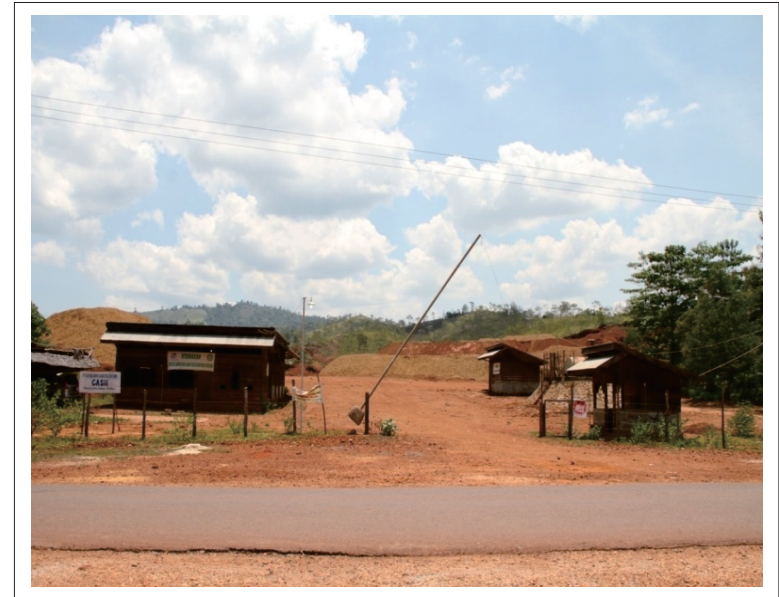

Gambar 6. Kondisi jalan kawasan pertambangan Nikel Puriala, dan morfologi dekat Taman Nasional

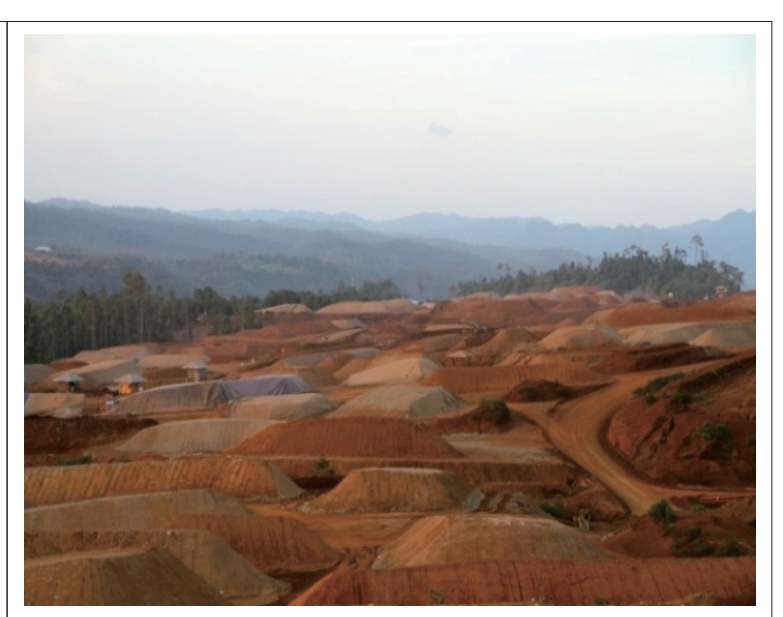

Gambar 7. Kondisi Stock file Pertambangan PT Stargate daerah Langikima, Konawe Utara 
Tabel 8.

Rekapitulasi karakteristik Wilayah dan Nilai Valuasi Rencana Kawasan Andalan Pertambangan Kabupaten Konawe dan Kabupaten Konawe Utara

\begin{tabular}{|c|c|c|c|c|c|c|}
\hline No & $\begin{array}{c}\text { Satuan } \\
\text { Genetika } \\
\text { Wilayah }\end{array}$ & Kecamatan & $\begin{array}{c}\text { sumber daya } \\
\text { ( juta ton) }\end{array}$ & Status IUP & $\begin{array}{c}\text { Tataguna } \\
\text { lahan }\end{array}$ & $\begin{array}{c}\text { Nilai } \\
\text { skenario } \\
\text { ditambang }\end{array}$ \\
\hline \multicolumn{7}{|c|}{ Konawe } \\
\hline 1 & $\begin{array}{l}\text { Pedataran } \\
\text { Batuan } \\
\text { Ultramafik }\end{array}$ & Pondidaha & 2,35 & $\begin{array}{l}\text { Operasi- } \\
\text { produksi }\end{array}$ & APL & $214-249$ \\
\hline 2 & $\begin{array}{l}\text { Pedataran } \\
\text { Patahan Batuan } \\
\text { Ultramafik }\end{array}$ & Routa & 249,25 & $\begin{array}{l}\text { Eksplorasi- } \\
\text { Operasi- } \\
\text { produksi }\end{array}$ & APL,HP & $207-229$ \\
\hline \multicolumn{7}{|c|}{ Konawe Utara } \\
\hline \multirow[t]{4}{*}{1} & \multirow{4}{*}{$\begin{array}{l}\text { Pedataran } \\
\text { Batuan } \\
\text { Ultramafik }\end{array}$} & Andowia & 74,60 & $\begin{array}{l}\text { Operasi } \\
\text { Produksi }\end{array}$ & APL, HP & $200-266$ \\
\hline & & Asera & 11,66 & $\begin{array}{l}\text { Eksplorasi- } \\
\text { Operasi- } \\
\text { produksi }\end{array}$ & $\begin{array}{l}\text { APL,HPK, } \\
\text { HP }\end{array}$ & $226-282$ \\
\hline & & Molawe & 55,98 & $\begin{array}{l}\text { Operasi } \\
\text { Produksi }\end{array}$ & APL, HP & $236-298$ \\
\hline & & Wiwirano & 31.83 & Eksplorasi & HPK & 264 \\
\hline \multirow[t]{2}{*}{2} & \multirow{2}{*}{$\begin{array}{l}\text { Pedataran } \\
\text { Patahan Batuan } \\
\text { Ultramafik }\end{array}$} & Wiwirano & 12.13 & $\begin{array}{c}\text { Operasi } \\
\text { Produksi }\end{array}$ & HPK & 252 \\
\hline & & Langikima & 1.077 & $\begin{array}{c}\text { Operasi } \\
\text { Produksi - } \\
\text { Eksplorasi }\end{array}$ & HP & $248-264$ \\
\hline
\end{tabular}

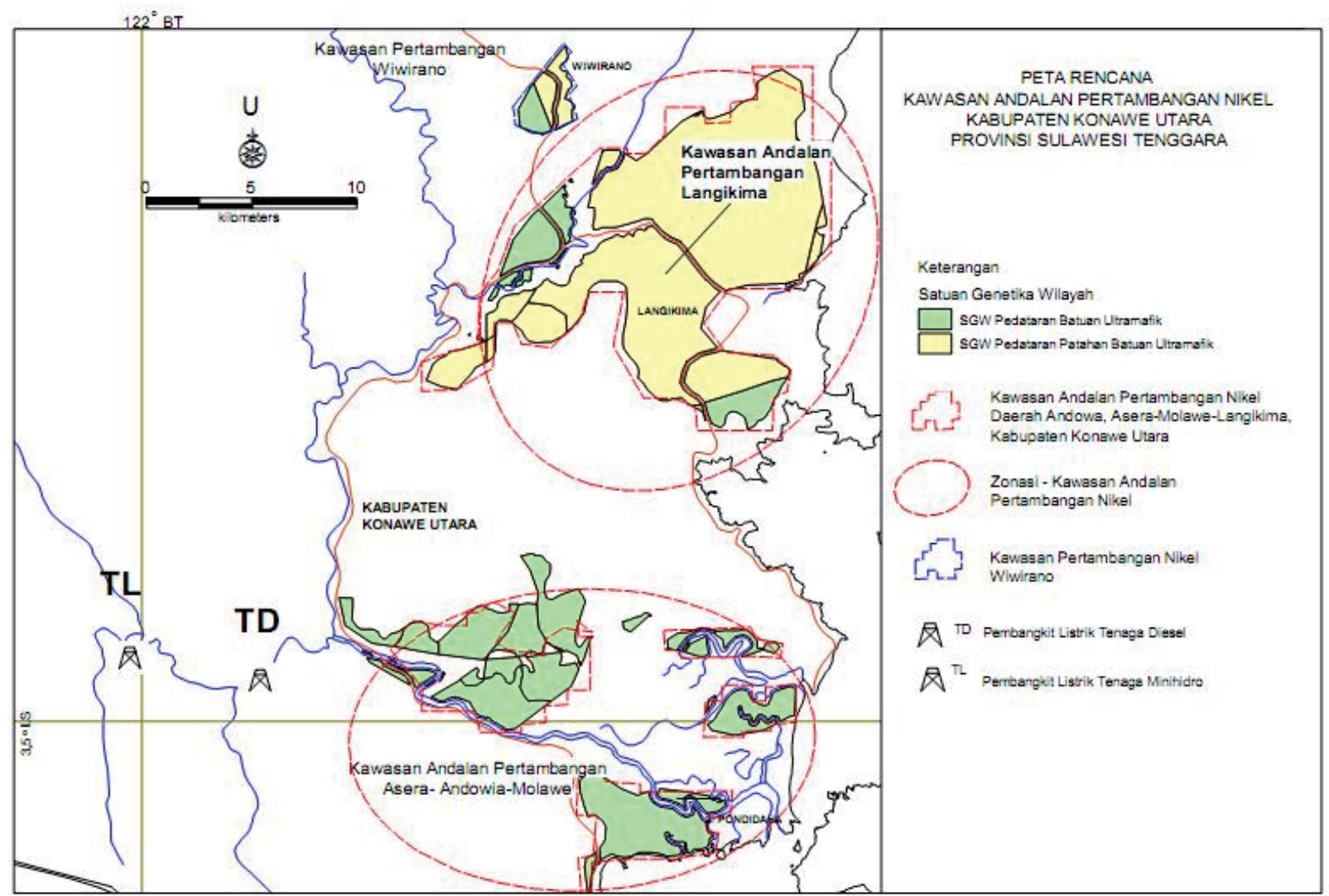

Gambar 8. Peta Rencana Pengembangan Kawasan Andalan Pertambangan Kabupaten Konawe Utara, Sulawesi Tenggara 


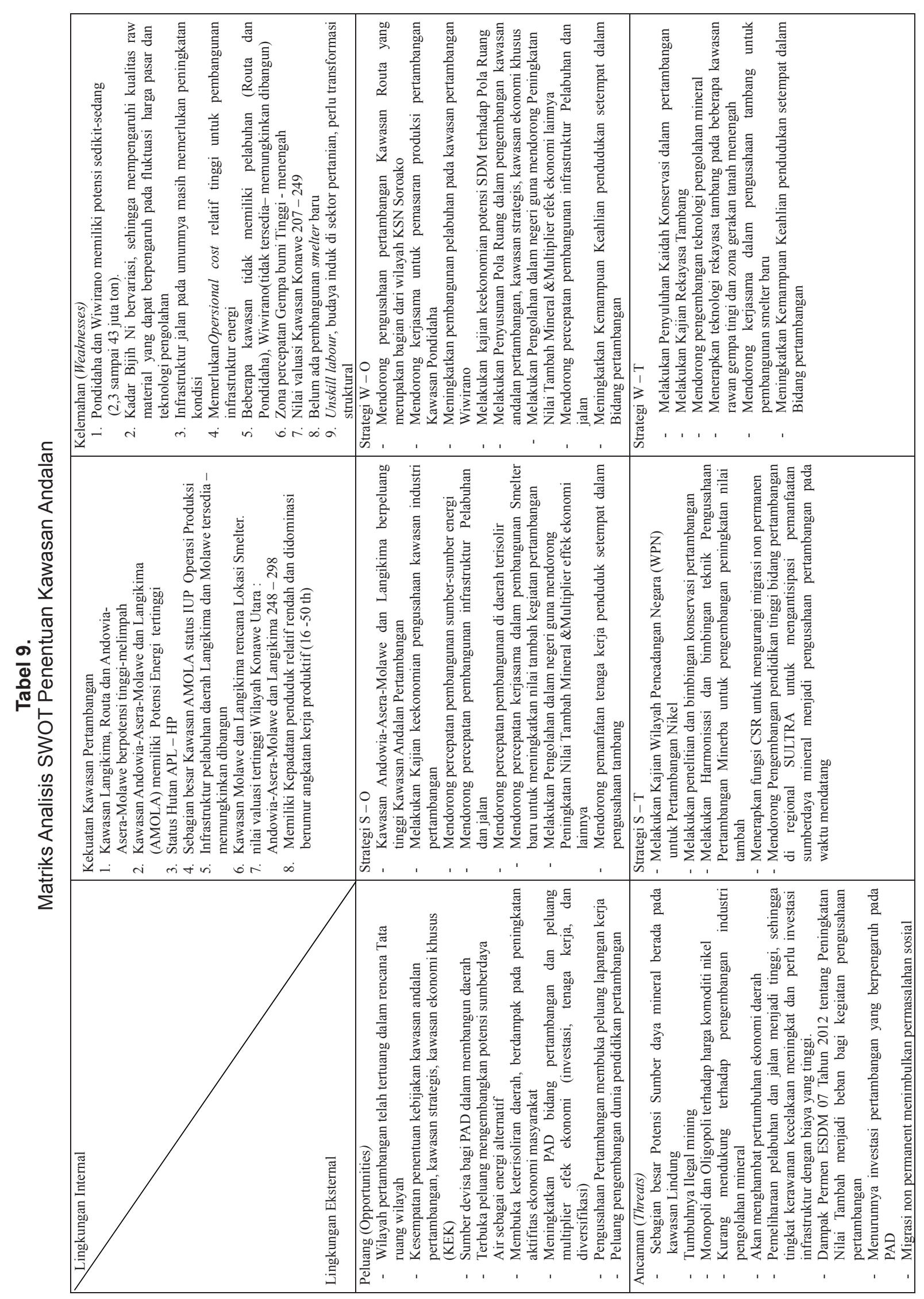




\section{KESIMPULAN}

Terdapat keterkaitan nilai potensi dan kendala wilayah dari unit-unit karakteristik wilayah terhadap total nilai valuasi SGW skenario ditambang /dikembangkan. Wilayah yang berpotensi tinggi untuk dikembangkan sebagai kawasan pertambangan Nikel adalah : Daerah Routa, Pondidaha Kabupaten Konawe dan Daerah Asera,Andowia, Oheo, Wiwirano, Molawe dan Langikima Kabupaten Konawe Utara.

Daerah Langikima dan Wiwirano SGW Pedataran Patahan Batuan Ultramafik serta daerah Andowia-Asera, Wiwirano dan Molawe SGW Pedataran Batuan Ultramafik pada Kabupaten Konawe Utara dapat direkomendasikan sebagai Kawasan Andalan Pertambangan Nikel.

\section{UCAPAN TERIMAKASIH}

Penulis mengucapkan terima kasih pada Nugroho W Wibowo, Emi Sukiyah dan Edi Tri Haryono, Syafrudin dan juga kepada semua pihak yang telah memberikan masukan dalam penulisan makalah ini.

\section{DAFTAR PUSTAKA}

Anonim.2011a. Peraturan Presiden No. 32 Tahun 2011 Tentang Masterplan Percepatan Dan Peluasan Pembangunan Nasional. Kementerian Koordinator Bidang Perekonomian. Jakarta.

Anonim. 2011b. Pemuthakiran Neraca Sumberdaya Mineral Tahun 2011.Badan Geologi. Pusat Sumber DayaGeologi. Bandung.

Anonim. 2011c. Peraturan Pemerintah No. 38 Tahun 2011, Tentang Sungai.

Gilbert, John and Park, Charles. F. 1986. The Geology of Ore Deposits, United States of America. Newyork. page 785-788.

Hirnawan, Febri. 2005. Peta Genetika Wilayah. Disertai Valuasi Karakteristik, Potensi, Dan Kendalanya Untuk Penataan Ruang dan Pengembangan wilayahTerbaik. Universitas Padjajaran. Bandung.

Hirnawan, Febri. 2009. Riset Bergulirlah Proses Ilmiah Program Pascasarjana. Universitas Padjadjaran. Bandung.

Ignasius L dan Nurseffi, D.W. 2012. Ekspor nikel Indonesia turun 90\%. dalam steelindonesia.com diunduh Oktober 2012.

Moetamar. 2007. Inventarisasi Endapan Nikel Di Kabupaten Konawe, Provinsi Sulawesi Tenggara. Proceding-Kolokium. Badan Geologi. Pusat Sumber Daya Geologi Bandung.

Nuarsa I Wayan. 2004. Mengolah Data Spasial dengan Map info Profesional. Andi.Yogjakarta.

Rusmana,E, Sukido, Sukarna. D., Haryanto 1993. Peta Geologi Lembar Lasusua - Kendari, Sulawesi. Skala 1: 250.000 . Pusat Penelitian dan Pengembangan Geologi (P3G). Bandung.

Smirnov, V.I.. 1976. Geology Of Mineral Deposits. Chapter 11. Deposits of Weathering. Moscow. Russian. Page 364.

Sutisna, Deddy\& Sunuhadi, D.N. 2006. Perencanaan Eksplorasi Cebakan Nikel Laterit Di Daerah Wayamli, Teluk Buli, Halmahera Timur - Sebagai Model Perencanaan Eksplorasi Cebakan Nikel Laterit di Indonesia. Pusat Sumber Daya Geologi. Bandung.

Swamidharma, Yoseph. 2011. Nickel Laterite Contents and Grades in Sulawesi. PT. Tint Mineral Indonesia. PROCEEDINGS OF THE SULAWESI MINERAL RESOURCES 2011 SEMINAR MGEI - IAGI., Manado, North Sulawesi, Indonesia. 